\title{
Variability of gluten intolerance in treated childhood coeliac disease
}

\author{
B. McNICHOLL, B. EGAN-MITCHELL, AND P. F. FOTTRELL \\ From the Department of Paediatrics, Regional Hospital and University College, and \\ Department of Biochemistry, University College, Galway
}

SUMMARY Fifty children consecutively attending a clinic for coeliac disease co-operated in a trial; 10 found to have flat mucosa were excluded. Forty children of mean age 9.8 years, whose duodenal or jejunal mucosa had returned to normal or near normal appearance after a mean of 5.8 years on gluten-free diets, were put back on normal diets. In 37, mucosal relapse occurred in a mean of 16.9 months (four to 74 months). Four of the 37 had serial biopsies, in which mucosal enzymes (particularly lactase) fell and interepithelial lymphocyte counts rose before the mucosal morphology was regarded as definitely 'coeliac'. Three children had normal mucosal appearance after 58 to 73 months on normal diets, one of whom showed temporary mucosal abnormalities, another having occasionally low enzymes, in both suggesting underlying gluten sensitivity. Lactase suppression and raised IEL counts appear to be sensitive indicators of gluten intolerance. In our experience, a diagnosis of coeliac disease based on severe mucosal damage and a satisfactory response to a glutenfree but milk-containing diet implies a very strong likelihood of permanent or prolonged gluten intolerance, but with a striking variability in its expression.

This study was an attempt to confirm our belief that a diagnosis of coeliac disease in childhood implied persistent wheat gluten intolerance, so that counselling of patients to permanently abstain from gluten would have a firm basis. Gerrard et al. (1955) and Sheldon (1969), from studies of adults diagnosed in childhood to have coeliac disease, concluded that gluten intolerance was permanent. Shmerling (1969), Visakorpi et al. (1970), Young and Pringle (1971), and Hamilton and McNeill (1972) concluded that gluten intolerance was permanent in 62 of 65 children thought to have coeliac disease, when mucosal relapse followed gluten refeeding. One of the 23 studied by Visakorpi et al. (1970) had a normal mucosa after six years on gluten but the original diagnosis had not been confirmed by intestinal biopsy, and of the 20 children challenged by Young and Pringle, biopsy failed in one and the other still had normal mucosa when lost to follow-up after two years on gluten. Rolles et al. (1975) regarded gluten intolerance as established in 15 of 16 children challenged with $20 \mathrm{~g}$ gluten daily, 11 on the basis of impaired xylose absorption and four with impaired xylose absorption and mucosal relapse; one child was thought not to have coeliac disease, despite

Received for publication 14 August 1978 characteristic biopsy changes initially, because of histologically normal mucosa one, three, six, and 18 months after gluten challenge; no details of cytology or enzyme assays were given.

Several groups have described histological, electron microscopic, or enzymatic change in the upper intestinal mucosa within hours or days of gluten feeding to coeliacs in remission; these include Rubin et al. (1962), Schenk and Samloff (1968), Jos et al. (1969), Shmerling and Shiner (1970), Bayless et al. (1970), and Pena et al. (1972).

\section{Methods}

PATIENTS

The parents of 50 children were asked, as they appeared consecutively for routine review, if they would co-operate in a trial of normal diets for the reasons given above and all consented. On biopsy, 10 children were found to have persisting severe mucosal damage, which appeared to be due to lax dietary control; they were regarded as having active coeliac disease and advised to follow a stricter gluten-free diet. Forty children, aged 3.25 years to 15.3 years (mean age 9.8 years), whose mucosa had returned to normal or near normal, and who had been on gluten-free diets for a mean of 5.8 years 
( 2.75 to 11 years) were advised to return to normal diets without any attempt being made to monitor their intake of gluten. None was advised to take iron or vitamin supplements during the trial. The initial diagnosis had been based on grade II or III mucosal changes (McNicholl and Egan, 1968) in 32 children and on similar appearance reported in other hospitals in two children; five children had been treated with gluten-free diets before their first biopsy, which showed normal or slightly abnormal appearance and one child had had no initial biopsy. Treatment was started at a mean age of 3.3 years $(0.65$ to 8.7 years). All 40 children had improved satisfactorily on treatment and details of the clinical and mucosal findings in 36 of them have been reported separately (McNicholl et al., 1976). In the majority, height, weight, epithelial cell height, interepithelial lymphocytes, lamina propria lymphoid cells, mucosal sucrase, and alkaline phosphatase returned to normal values. Mucosal lactase, however, remained significantly lower than in controls.

Biopsies were obtained with $8 \mathrm{~mm}$ Crosby capsules having $3 \mathrm{~mm}$ ports, from the distal duodenum or proximal jejunum. Grade 0 represents normal mucosa, I slight, II moderate, and III severe mucosal damage, grades II and III being regarded as consistent with active coeliac disease. Interepithelial lymphocytes (IEL) were counted per 500 epithelial cell nuclei on $7 \mu$ sections stained with haematoxylin and eosin or periodic acid Schiff and expressed per 1000 cells; counts were started at the crypt-villus junction and included the whole extent of the villus; in flat mucosa the counts were made between the openings of the crypts.

Mucosal protein was assayed by the method of Lowry et al. (1951), disaccharidases by the method of Dahlqvist (1968), and alkaline phosphatase by the method of Kelly and Hamilton (1970). Controls for the lymphocyte counts and enzyme assays were
25 children aged 5 to 17.9 years (mean 9.9 years), selected from normal siblings of coeliacs in a family study (Mylotte et al., 1974). These controls differ from those used in the preliminary report of this study (McNicholl et al., 1974), being selected to ensure better comparability of ages. Controls for IgA were 28 children aged 5-9.9 years and 23 aged 10-13.9 years, from a local study of population exposure to lead (Grimes 1975). Haemoglobin was measured by a cyanomethaemoglobin method in a Technicon SMA analyser, serum iron by a bathophenanthroline disulphonate method, serum folate by the $L$. casei method, and immunoglobulins by the Mancini radial immunodiffusion technique. Serum folate was assayed in two other laboratories as well as our own at different times, a 'low' level indicating one below the range accepted in the particular laboratory. Height and weight were plotted on the charts of Tanner and Whitehouse (1959). Investigation was confined to anthropometry, venepuncture, and intestinal biopsy as we had assured parents that review would not involve them in more than a morning's attendance on any occasion. Xylose absorption was not tested as some coeliac children had experienced occasional nausea and vomiting after its administration. Values for controls are given in Table 1.

\section{Results}

In 37 children the mucosa reverted to GII or GIII in a mean of 16.9 months (four to 74 months). These 37 children include the child treated without initial biopsy, the two children diagnosed elsewhere, and the five children treated before their initial biopsy, thus confirming the initial diagnosis in all 37. Seventeen of the 37 were under the age of 2 years at the time of diagnosis, and three were less than 1 year old. Of the 37 children, overt symptoms

Table 1 Control values, giving mean and one standard deviation for $\operatorname{Ig} A$, interepithelial lymphocytes, mucosal lactase, sucrase and alkaline phosphatase

\begin{tabular}{|c|c|c|c|c|c|}
\hline & Age (yr) & $N$ & & Mean & $1 S D$ \\
\hline IgA & 5- 9.9 & & 28 & $1 \cdot 29$ & 0.54 \\
\hline$(\mathrm{g} / \mathrm{l})$ & $10-13.9$ & & 23 & 1.65 & 0.79 \\
\hline Lactase & & Duo & 9 & 37.6 & $19 \cdot 3$ \\
\hline (IU/g & & Jej & 16 & $62 \cdot 8$ & 21.6 \\
\hline $\begin{array}{l}\text { protem) } \\
\text { Sucrase }\end{array}$ & $5-17 \cdot 9$ & Duo & 9 & 58.0 & $33 \cdot 7$ \\
\hline $\begin{array}{l}\text { (IU/g } \\
\text { protein) }\end{array}$ & & Jej & 16 & 86.9 & $30 \cdot 1$ \\
\hline Alkaline & & Duo & 9 & $22 \cdot 2$ & $7 \cdot 6$ \\
\hline $\begin{array}{l}\text { pros/mg } \\
\text { protein) }\end{array}$ & & Jej & 16 & 28.9 & $7 \cdot 4$ \\
\hline
\end{tabular}

Duo: Duodenum. Jej: Jejunum. IEL: Interepithelial lymphocytes. 
appeared in six, who were biopsied between four and 14 months (mean nine months) after starting a normal diet; three of them had impaired growth as shown by a fall of five or more height centiles and one had a low serum iron (less than $11 \mu \mathrm{mol} / \mathrm{l}$ ). Fifteen children had no overt symptoms but had falls of between 5 and 20 height centiles, 11 of them had falls of 5 to 35 weight centiles; they were biopsied at a mean of 19 months (nine to 34 months), by which time four had low serum folate and two low serum iron levels. Four children who had no symptoms or growth impairment had low serum folate levels and two of them had low serum iron when biopsied at a mean of 30 months (12 to 28 months). Eleven children biopsied at a mean of 24 months (11 to 35 months) had shown no symptoms or growth impairment, but serial blood examinations were not complete. Only one child was found to have a haemoglobin level below $12 \mathrm{~g} / \mathrm{dl}$ at any time of the study, a boy of $7 \frac{1}{2}$ years whose haemoglobin had fallen from $13.8 \mathrm{~g}$ to $11.8 \mathrm{~g}$ after one year on a normal diet, but whose serum iron at that time was $13 \mu \mathrm{mol} / 1$ and who had had no symptoms or growth impairment. The 37 th child, case 37 , is described in detail.

Four of the 37 had serial biopsies, cases $34,35,36$, and 37 (Table 2), their histology not being regarded as definitely indicating recurrence of active coeliac disease until they had been 25 to 74 months on normal diet. Case 34 had minimal mucosal morphological abnormality, a normal IEL count, and a low lactase at the beginning of the trial, and, although the IEL count had risen and the lactase fallen after
21 months on normal diet, the mucosal appearance had otherwise not worsened; after 33 months on normal diet, the mucosa was severely abnormal with very low lactase, sucrase, and alkaline phosphatase. Case 35 showed low lactase and high IEL counts in the biopsies after one and four months on normal diet, but severe mucosal damage with very low enzyme levels after 25 months. Case 36 had mild morphological changes and a low lactase after 21 months on ND, followed by more characteristic changes in morphology, IEL, and mucosal enzymes at 26 months. Case 36 had low serum iron and folate at the conclusion of the trial, but the other two children showed no biochemical abnormality.

Case 37 (Table 2) had been on a gluten free diet for 57 months from the time of clinical diagnosis at age 16 months. During her first year on normal diet her gluten intake probably did not exceed 2 to $5 \mathrm{~g}$ daily but thereafter gradually increased. Biopsies at 28 and 35 months, while not acceptable as fully normal, could by no means be regarded as compatible with active coeliac disease. those at 47 and 56 months showed mild to moderate abnormality, and at 59 months (Figure, a) still showed villi with reasonably good epithelium, although with increased IEL and lamina propria lymphoid cells. Biopsy at 63 months was compatible with coeliac disease, but in view of the preceding variability in mucosal appearance we decided to allow continuation of a normal diet, biospy at 68 months showing some slight improvement. At 74 months three distal duodenal and two proximal jejunal biopsies were taken with a multiple biopsy tube and all were regarded as typical of

Table 2 Sex, age, height and weight centiles, biopsy site and grade, interepithelial lymphocytes, mucosal lactase, sucrase and alkaline phosphatase at remission and during gluten feeding in four coeliac children

\begin{tabular}{|c|c|c|c|c|c|c|c|c|c|c|}
\hline \multicolumn{2}{|c|}{$\begin{array}{l}\text { Case no, } \\
\text { Sex, age (yr) }\end{array}$} & \multirow{2}{*}{$\begin{array}{l}\text { Months } \\
\text { on ND } \\
\text { ND } \\
21 \\
33\end{array}$} & \multirow{2}{*}{$\begin{array}{l}\begin{array}{c}\text { Height } \\
\text { centile }\end{array} \\
80 \\
70 \\
70\end{array}$} & \multirow{2}{*}{$\begin{array}{l}\begin{array}{l}\text { Weight } \\
\text { centile }\end{array} \\
90 \\
85 \\
70\end{array}$} & \multirow{2}{*}{$\begin{array}{c}\begin{array}{l}\text { Mucosal } \\
\text { grade }\end{array} \\
\text { O/I } \\
\text { O/I } \\
\text { III }\end{array}$} & \multirow{2}{*}{$\begin{array}{l}\text { Site } \\
\text { Jej } \\
\text { Jej } \\
\text { Duo }\end{array}$} & \multirow{2}{*}{$\begin{array}{l}I E L(p e r \\
\left.10^{3} E C\right) \\
70 \\
427 \\
468\end{array}$} & \multirow{2}{*}{$\begin{array}{c}\begin{array}{c}\text { Lactase } \\
\text { (IU/g prot) }\end{array} \\
19.0 \\
6.1 \\
0.5\end{array}$} & \multirow{2}{*}{$\begin{array}{l}\begin{array}{l}\text { Sucrase } \\
\text { (IU/g prot) }\end{array} \\
\\
12 \cdot 2 \\
8.6\end{array}$} & \multirow{2}{*}{$\begin{array}{l}\begin{array}{l}\text { Alk phos } \\
\text { (IU/mg prot) }\end{array} \\
7.6 \\
8.0\end{array}$} \\
\hline $\begin{array}{r}34 \\
q\end{array}$ & 7 & & & & & & & & & \\
\hline $\begin{array}{r}35 \\
q\end{array}$ & $13 \cdot 2$ & $\begin{array}{c}\text { ND } \\
1 \\
4 \\
25\end{array}$ & $\begin{array}{l}75 \\
75 \\
75 \\
75\end{array}$ & $\begin{array}{l}50 \\
30 \\
\\
80\end{array}$ & $\begin{array}{r}\text { O/I } \\
\text { O/I } \\
\text { I } \\
\text { III }\end{array}$ & $\begin{array}{l}\text { Duo } \\
\text { Duo } \\
\text { Duo } \\
\text { Duo }\end{array}$ & $\begin{array}{l}150 \\
600 \\
350 \\
531\end{array}$ & $\begin{array}{l}4 \cdot 3 \\
4 \cdot 3 \\
2 \cdot 1\end{array}$ & 8.9 & 7.9 \\
\hline $\begin{array}{r}36 \\
\delta\end{array}$ & $13 \cdot 7$ & $\begin{array}{l}\text { ND } \\
21 \\
26\end{array}$ & $\begin{array}{l}4 \\
7\end{array}$ & $\begin{array}{l}35 \\
30\end{array}$ & $\begin{array}{r}\text { O/I } \\
\text { I } \\
\text { II }\end{array}$ & $\begin{array}{l}\text { Duo } \\
\text { Duo } \\
\text { Jej }\end{array}$ & $\begin{array}{l}259 \\
311 \\
680\end{array}$ & $\begin{array}{r}10 \cdot 1 \\
10 \cdot 8 \\
6.3\end{array}$ & $\begin{array}{l}22 \cdot 0 \\
14 \cdot 2\end{array}$ & $\begin{array}{r}10.8 \\
6.5\end{array}$ \\
\hline $\begin{array}{r}37 \\
9\end{array}$ & 6 & $\begin{array}{l}\text { ND } \\
28 \\
35 \\
47 \\
56 \\
59 \\
63 \\
68 \\
74\end{array}$ & $\begin{array}{l}70 \\
80 \\
80 \\
75 \\
80 \\
75 \\
75 \\
75 \\
75\end{array}$ & $\begin{array}{l}87 \\
80 \\
80 \\
80 \\
65 \\
70 \\
65 \\
65 \\
75\end{array}$ & $\begin{array}{r}\mathbf{O} \\
\mathbf{O} / \mathbf{I} \\
\mathbf{O} / \mathbf{I} \\
\mathbf{O} / \mathbf{I} \\
\mathbf{I} / \mathbf{I I} \\
\mathbf{I} \\
\mathbf{I I} \\
\mathbf{I} / \mathbf{I I} \\
\mathbf{I I} / \mathbf{I I I}\end{array}$ & $\begin{array}{l}\text { Duo } \\
\text { Duo } \\
\text { Duo } \\
\text { Duo } \\
\text { Duo } \\
\text { Duo } \\
\text { Duo } \\
\text { Duo } \\
\text { Jej }\end{array}$ & $\begin{array}{l}228 \\
257 \\
415 \\
357 \\
514 \\
416 \\
660 \\
472 \\
618\end{array}$ & $\begin{array}{r}112.0 \\
19.6 \\
16.5 \\
13.1 \\
3.1 \\
3.0 \\
2.6 \\
2.5 \\
2.5\end{array}$ & $\begin{array}{r}32 \cdot 3 \\
44 \cdot 0 \\
47 \cdot 7 \\
13 \cdot 7 \\
16 \cdot 7 \\
8 \cdot 9 \\
9 \cdot 6 \\
8 \cdot 6\end{array}$ & $\begin{array}{r}23 \cdot 4 \\
16 \cdot 2 \\
7 \cdot 7 \\
5 \cdot 3 \\
7 \cdot 5 \\
3 \cdot 4 \\
3 \cdot 6 \\
7.9\end{array}$ \\
\hline
\end{tabular}

Age : at start of normal gluten-containing diet (ND). IEL: interepithelial lymphocytes per 1000 epithelial cells. Alk phos: alkaline phosphatase. 

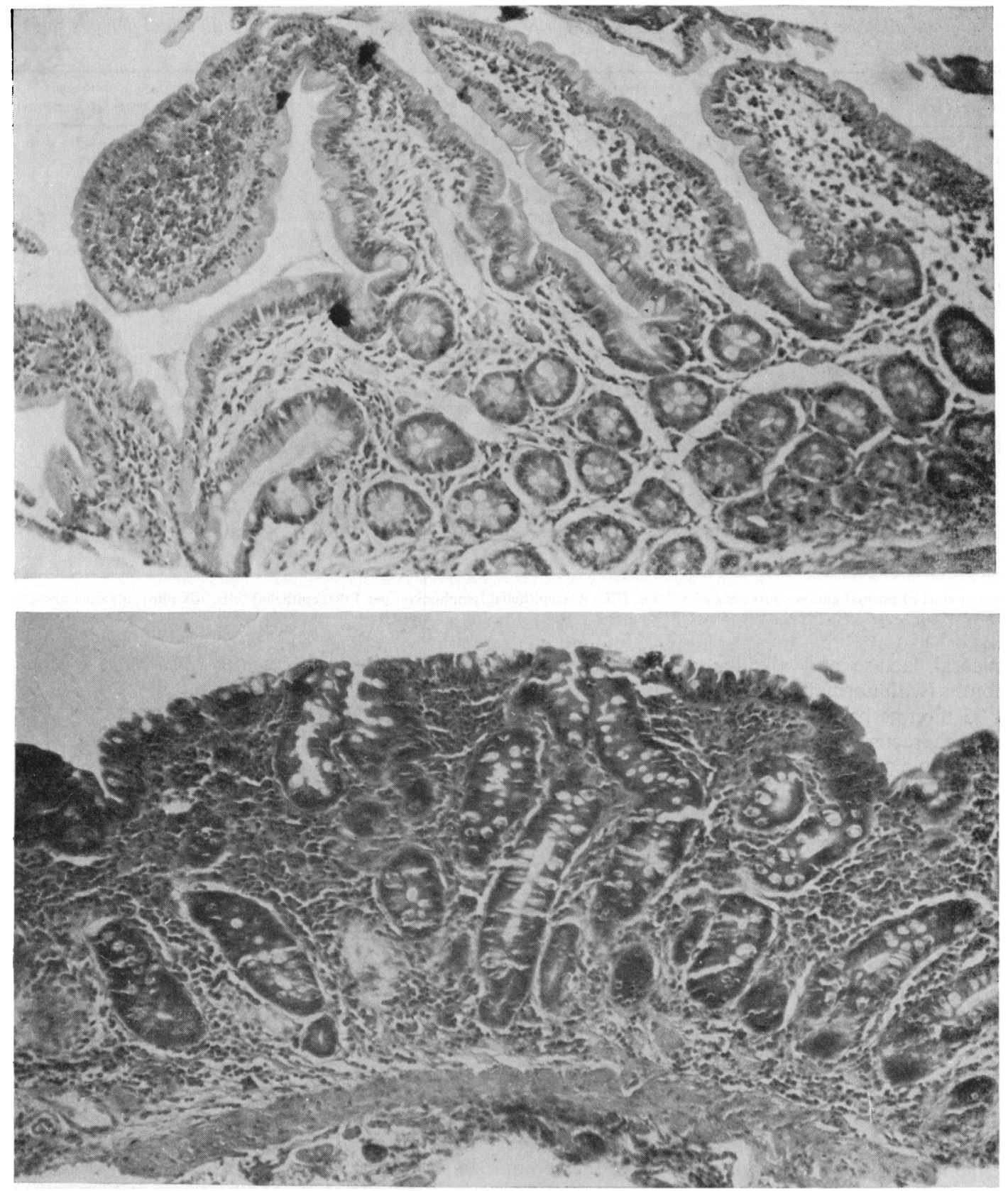

Figure (a) Partly tangential section of duodenal mucosa after 59 months on normal diet. (b) Proximal jejunal mucosa after 74 months on normal diet.

active coeliac disease (Figure, b) and a permanent gluten free diet was advised. The three remaining children, cases 40,39 , and 38 still had normal mucosal morphology when last biopsied after 70 , 85 , and 65 months respectively on normal diet
(Table 3); their initial diagnosis had been made at ages 6,15 , and 68 months respectively. Cases 40 and 39 had a low serum iron after 19 and 17 months respectively on a normal diet, followed by a spontaneous return to normal levels; case 39 had a low 
Table 3 Sex, age, height and weight centiles, biopsy site and grade, interepithelial lymphocytes, mucosal lactase, sucrase and alkaline phosphatase at remission and during gluten feeding in three children with initial diagnosis of coeliac disease

\begin{tabular}{|c|c|c|c|c|c|c|c|c|c|c|}
\hline \multicolumn{2}{|c|}{$\begin{array}{l}\text { Case no. } \\
\text { sex, age (yr) }\end{array}$} & \multirow[t]{2}{*}{$\begin{array}{l}\text { Months } \\
\text { on ND }\end{array}$} & \multirow[t]{2}{*}{$\begin{array}{l}\text { Height } \\
\text { centile }\end{array}$} & \multirow[t]{2}{*}{$\begin{array}{l}\text { Weight } \\
\text { centile }\end{array}$} & \multirow[t]{2}{*}{$\begin{array}{l}\text { Mucosal } \\
\text { grade }\end{array}$} & \multirow[t]{2}{*}{ Site } & \multirow[t]{2}{*}{$\begin{array}{l}\text { IEL per } \\
10^{3} \mathrm{EC}\end{array}$} & \multirow[t]{2}{*}{$\begin{array}{l}\text { Lactase } \\
\text { (IU/g prot) }\end{array}$} & $\begin{array}{l}\text { Sucrase } \\
\text { (IU/g prot })\end{array}$ & \multirow[t]{2}{*}{$\begin{array}{l}\text { Alk phos } \\
\text { (IU/mg prot })\end{array}$} \\
\hline 40 & & & & & & & & & & \\
\hline 우 & $3 \cdot 2$ & $\begin{array}{l}\text { ND } \\
15 \\
19 \\
32 \\
46 \\
58 \\
70\end{array}$ & $\begin{array}{l}50 \\
50 \\
50 \\
50 \\
50 \\
50 \\
45\end{array}$ & $\begin{array}{l}87 \\
87 \\
95 \\
75 \\
75 \\
75 \\
70\end{array}$ & $\begin{array}{l}0 \\
0 \\
0 \\
0 \\
0 \\
0 \\
0\end{array}$ & $\begin{array}{l}\text { Duo } \\
\text { Duo } \\
\text { Duo } \\
\text { Jej } \\
\text { Duo } \\
\text { Duo } \\
\text { Duo }\end{array}$ & $\begin{array}{r}147 \\
173 \\
74 \\
198 \\
220 \\
388 \\
298\end{array}$ & $\begin{array}{l}28.6 \\
28 \cdot 1 \\
20.8 \\
59.7 \\
78.8 \\
24.9 \\
37 \cdot 2\end{array}$ & $\begin{array}{l}62 \cdot 3 \\
57 \cdot 3 \\
46 \cdot 7 \\
77 \cdot 2 \\
45 \cdot 7 \\
42 \cdot 5 \\
45 \cdot 0\end{array}$ & $\begin{array}{l}17 \cdot 4 \\
22 \cdot 4 \\
13 \cdot 5 \\
16 \cdot 5 \\
18 \cdot 9 \\
11 \cdot 9 \\
15 \cdot 1\end{array}$ \\
\hline 39 & & & & & & & & & & \\
\hline$\delta$ & 7 & $\begin{array}{l}\text { ND } \\
17 \\
29 \\
35 \\
47 \\
61 \\
73 \\
85\end{array}$ & $\begin{array}{l}80 \\
85 \\
85 \\
85 \\
85 \\
90 \\
90 \\
85\end{array}$ & $\begin{array}{l}80 \\
85 \\
85 \\
85 \\
85 \\
75 \\
75 \\
65\end{array}$ & $\begin{array}{l}0 \\
0 \\
0 \\
0 \\
0 \\
0 \\
0 \\
0\end{array}$ & $\begin{array}{l}\text { Jej } \\
\text { Duo } \\
\text { Duo } \\
\text { Duo } \\
\text { Duo } \\
\text { Duo } \\
\text { Duo } \\
\text { Duo }\end{array}$ & $\begin{array}{l}100 \\
116 \\
264 \\
194 \\
320 \\
186 \\
180 \\
164\end{array}$ & $\begin{array}{r}52.0 \\
22.8 \\
22.7 \\
20.8 \\
15.8 \\
22 \cdot 1 \\
0.6 \\
22.7\end{array}$ & $\begin{array}{r}34 \cdot 4 \\
36 \cdot 2 \\
49 \cdot 4 \\
36 \cdot 7 \\
43 \cdot 4 \\
5 \cdot 5 \\
37 \cdot 3\end{array}$ & $\begin{array}{r}11.6 \\
20.1 \\
12.9 \\
10.0 \\
11.7 \\
8.1 \\
11.4\end{array}$ \\
\hline 38 & & & & & & & & & & \\
\hline 우 & $11 \cdot 5$ & $\begin{array}{l}\text { ND } \\
25 \\
33 \\
47 \\
53 \\
65\end{array}$ & $\begin{array}{l}45 \\
\\
32 \\
40 \\
40 \\
40\end{array}$ & $\begin{array}{r}8 \\
8 \\
20 \\
15 \\
20 \\
30\end{array}$ & $\begin{array}{l}0 \\
0 / \mathbf{I} \\
\mathbf{I} \\
0 \\
0 \\
0\end{array}$ & $\begin{array}{l}\text { Jej } \\
\text { Duo } \\
\text { Duo } \\
\text { Duo } \\
\text { Jej } \\
\text { Jej }\end{array}$ & $\begin{array}{l}106 \\
287 \\
305 \\
264 \\
194 \\
194\end{array}$ & $\begin{array}{r}24 \cdot 2 \\
11.7 \\
9.7 \\
14.4 \\
69.4\end{array}$ & $\begin{array}{r}56 \cdot 4 \\
54 \cdot 3 \\
29 \cdot 7 \\
49 \cdot 1 \\
119 \cdot 6\end{array}$ & $\begin{array}{l}17 \cdot 6 \\
14 \cdot 0 \\
15 \cdot 5 \\
10 \cdot 8 \\
16 \cdot 5\end{array}$ \\
\hline
\end{tabular}

Age: at start of normal gluten-containing diet (ND). IEL: interepithelial lymphocytes per 1000 epithelial cells. Alk phos: alkaline phosphatase.

mucosal lactase and alkaline phosphatase at 47 months (with normal sucrase) and a rise in IEL, and at 73 months had a fall in all enzyme activities to levels characteristic of active coeliac disease, but with normal mucosal appearance, followed by a return to normal levels in the next biopsy. Case 38 after 33 months on normal diet had a fall of 13 height centiles, a serum iron of $9 \mu \mathrm{mol} / 1$, a rise in serum $\operatorname{IgA}$ to $3 \mathrm{~g} / 1$, and a definite deterioration in mucosal morphology accompanied by a fall in mucosal lactase, but subsequently all abnormalities gradually disappeared; she has not attended for review for three years.

The seven children serially biopsied were said to have been in normal health throughout the trial and showed only slight fluctuation in height and weight and the minor biochemical abnormalities mentioned; secondary sexual development has occurred normally in those of appropriate age. Haemoglobin did not fall below $12 \mathrm{~g} / \mathrm{dl}$ in any child, serum $\operatorname{IgA}$ remained within normal range in each of the seven, except on the one occasion in case 38. HL-A antigens are shown in Table 4.

\section{Discussion}

Thirty-seven of 40 children were proved to have a persisting gluten intolerance because of a recurrence of grade II or III morphology four to 74 months (mean 16.9 months) after they had returned to a
Table $4 \quad H L-A$ antigens in six children having serial biopsies

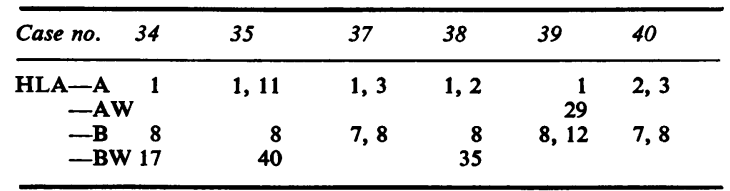

normal diet. Details of anthropometry and mucosal findings in relapse have been reported (McNicholl et al., 1976). As it is probable that in most children the mucosal relapse occurred some time before the definitive biopsy was taken, the mean duration of 16.9 months must be an overestimate.

Case 37 is notable for the long period on normal diet before definite morphological changes recurred, as well as for the fluctuation in these changes. We did not regard any mucosal specimen as definitely 'coeliac' until 63 months, although none was 'normal'. In contrast, mucosal lactase was below the normal range at 35 months, lower at 47 months, and very low thereafter; IEL counts had also been raised from 35 months. Low lactase levels, and/or high IEL counts, should raise suspicion of gluten intolerance, even if morphological changes are slight or indefinite. When mucosal enzyme assays are not readily available, reliance will have to be placed on general morphology and IEL counts. The dissecting microscope appearance of biopsies is helpful in a 
rapid assessment of the mucosal state and correlates reasonably well with the histological appearance; in case 37 some leaf and ridge villi were seen up to 68 months, and occasional low ridges were still found at 74 months. Correct orientation of mucosal specimens for histology is important for accurate assessment, but difficulties arise (as in Figure, a), particularly when only half to a third of a small specimen from a child is available, the remainder being reserved for enzymology. Multiple specimens give better scope for both histology and enzymology and are more representative, but children are less happy to have repeated encounters with the multiple biopsy tube than with a capsule.

Our initial policy having been to require grade II or III mucosal changes as proof of gluten intolerance, we would now accept lesser degrees of mucosal damage, when associated with low mucosal enzyme activities, particularly that of lactase, and with raised IEL counts. We would now regard as indicative of gluten intolerance the combination of histological and enzymological changes in the first post-gluten biopsies in cases 34,35 , and 36 , and in that at 56 months in case 37.

The contrast between the slow recurrence of mucosal relapse in cases 34,36 and 37, and the more rapid relapse found in some of our patients and by other authors must reflect considerable variability in gluten intolerance. Evidence for a direct correlation between gluten dosage and the speed and degree of mucosal relapse is conflicting. It seems possible that the low and gradually increasing intake of gluten in cases 34 and 37 may have contributed to the delay in the mucosal relapse, perhaps allowing some degree of hyposensitisation to gluten to occur. Another possibility, considering the absence of severe grade III morphology either initially or finally in case 37 , and the fluctuation in the degree or the patchiness of the mucosal damage, is that of a lesser degree of gluten intolerance - in other words, a less severe coeliac disease. It is also possible that the longish period on a gluten free diet before challenge in this series (mean 5.8 years) could lessen the degree of gluten intolerance or delay its reappearance. Although our allowance of an ad libitum diet was designed to reflect what happens when coeliac patients are allowed, for various reasons, to return to normal diets, the prescription of a specific amount of wheat products or gluten daily would seem to be a more reliable procedure; $10 \mathrm{~g}$ gluten daily is probably appropriate for most children.

As to the three children whose mucosa appeared normal at their latest investigation, we can only speculate as to their future. The temporary deterioration in case 38 and the intermittently low enzymes in case 110 are consistent with a variable state of gluten sensitivity; we believe that a reversion to active coeliac disease may take place sooner or later in these children, whatever may be said about case 40 . The initial illnesses in all three were not associated with acute diarrhoea, adverse environment or other known causes of flat mucosa and each responded to gluten-free, milk-containing diets, so that if they continue to have normal health and mucosae, temporary gluten-intolerance (WalkerSmith, 1970) will have to be considered. General acceptance has been given to the requirements of the European Society for Paediatric Gastroenterology for confirmation of the diagnosis of coeliac disease (Meeuwisse, 1970); these imply that the persistence of normal morphology of the intestinal mucosa after two years of gluten challenge excludes coeliac disease. In the light of some findings in this study, and also the lack of reference to IEL counts and enzymology, these requirements probably need to be modified, and there would also seem to be a need for an attempt to define mucosal normality, as well as a scale of mucosal abnormality.

In the west of Ireland, a flat mucosa which responds to a gluten-free and milk-containing diet is likely to be due to coeliac disease (acute enteritis and immunoglobulin deficiency being excluded), thus implying the need for a lifelong gluten-free diet. If such children are challenged with gluten, particularly after long periods on a gluten-free diet, the spectrum of response of the mucosa will be wide and variable. Gluten challenge, with the need for at least two and possibly several biopsies, together with the possible adverse effects of gluten, is probably unnecessary, although all coeliacs should have a biopsy every five years or so, and also whenever any suspicion of dietary lapse or ill health arises. To learn more of the life history of this disease, our three children with presently morphologically no mal mucosa, together with other children with similar clinical states in other centres, should be carefully and regularly reviewed.

Our thanks are due firstly to the children and their parents for their whole-hearted co-operation and then to many clinical and laboratory colleagues. We are indebted to Professor J. D. Kennedy and Dr M. Little for histological reports, Dr H. Grimes for the immunoglobulin assays, Professors C. F. McCarthy and D. Watt for the H-LA typing, Dr F. M. Stevens for the multiple biopsy in case 37 and S. Baker for lymphocyte counting. The many enzyme assays were made by $R$. Keane. The Medical Research Council of Ireland supported the enzyme assays and also a Fellowship for B.E.-M. Support from the Wellcome Trust and the Western Health Board is gratefully acknowledged. 


\section{References}

Bayless, T. M., Rubin, S. E., Topping, T. M., Yardley, J. H., and Hendrix, T. R. (1970). Morphologic and functional effects of gluten feeding on jejunal mucosa in celiac disease. In Coeliac Disease, pp. 76-89. Edited by C. C. Booth and R. H. Dowling. Churchill Livingstone: London.

Dahlquist, A. (1968). Assay of intestinal disaccharidases. Analytical Biochemistry, 22, 99-107.

Gerrard, J. W., Ross, C. A. C., Astley, R., French, J. M., and Smellie, J. M. (1955). Coeliac disease. Is there a natural recovery? Quarterly Journal of Medicine, 24, 23-32.

Grimes, H. (1975). Biological sampling for monitoring population exposure to lead. Galway Medical Annual, Special Edition, 121.

Hamilton, J. R., and McNeill, L. K. (1972). Childhood celiac disease; response of treated patients to a small uniform daily dose of wheat gluten. Journal of Pediatrics, 81, 885-893.

Jos, J., Rey, J., and Frézal, J. (1969). Effets precoce de la reintroduction du gluten sur la muqueuse intestinale dans la maladie coeliaque en remission. Archives Françaises de Pediatrie, 26, 849-859.

Kelly, M. H., and Hamilton, J. R. (1970). A microtechnique for the assay of intestinal alkaline phosphatase. Clinics in Biochemistry, 3, 33-43.

Lowry, O. H., Rosebrough, A. J., Farr, A. L., and Randall, R. J. (1951). Protein measurement with the folin phenol reagent. Journal of Biological Chemistry, 193, 265-275.

McNicholl, B., and Egan, B. (1968). Jejunal biopsy in celiac disease. Clinical Pediatrics, 7, 544-552.

McNicholl, B., Egan-Mitchell, B., Stevens, F., Keane, R., Baker, S., McCarthy, C. F., and Fottrell, P. F. (1976). Mucosal recovery in treated childhood celiac disease. Journal of Pediatrics, 89, 418-424.

McNicholl, B., Egan-Mitchell, B., and Fottrell, P. F. (1974). Varying gluten susceptibility in coeliac disease. In Coeliac Disease, pp. 413-418. Edited by W. T. J. M. Hekkens and A. S. Peña. Stenfert Kroese: Leiden.

Meeuwisse, G. W. (1970). Diagnostic criteria in coeliac disease: Round Table Discussion of the European Society for Paediatric Gastroenterology. Acta Paediatrica Scandinavica, 59, 461-463.

Mylotte, M., Egan-Mitchell, B., Fottrell, P. F., McNicholl, B., and McCarthy, C. F. (1974). Family studies in coeliac disease. Quarterly Journal of Medicine, New Series, 43,
359-369.

Peña, A. S., Truelove, S. C., and Whitehead, R. (1972). Disaccharidase activity and jejunal morphology in coeliac disease. Quarterly Journal of Medicine New Series, 41, 457-476.

Rubin, C. E., Brandberg, L. L., Flick, A. L., Phelps, P., Parmentier, C., and Van Niel, S. (1962). Studies of celiac sprue, III. The effect of repeated wheat instillation into the proximal ileum of patients on a gluten-free diet. Gastroenterology, 43, 621-641.

Rolles, C. J., Anderson, C. M., and McNeish, A. S. (1975). Confirming persistence of gluten intolerance in children diagnosed as having coeliac disease in infancy: usefulness of one-hour blood xylose test. Archives of Disease in Childhood, 50, 259-263.

Schenk, E. A., and Samloff, I. M. (1968). Clinical and morphologic changes following gluten administration to patients with treated celiac disease. American Journal of Pathology, 52, 579-585.

Sheldon, W. (1969). Prognosis in early adult life of coeliac children treated with a gluten-free diet. British Medical Journal, 2, 401-404.

Shmerling, D. H. (1969). An analysis of controlled relapses in gluten induced coeliac disease (Abstract). Acta Paediatrica Scandinavica, 58, 311.

Shmerling, D. H., and Shiner, M. (1970). The response of the intestinal mucosa to the intraduodenal instillation of gluten in patients with coeliac disease during remission: In Coeliac Disease, pp. 64-74. Edited by C. C. Booth and R. H. Dowling. Churchill Livingstone: London.

Tanner, J. M., and Whitehouse, R. H. (1959). Standards for height and weight of British children from birth to maturity (Letter). Lancet, 2, 1086.

Visakorpi, J. K., Kuitunen, P., and Savilahti, E. (1970). Frequency and nature of relapses in children suffering from the malabsorption syndrome with gluten intolerance. Acta Paediatrica Scandinavica, 59, 481-486.

Walker-Smith, J. (1970). Transient gluten intolerance. Archives of Disease in Childhood, 45, 523-526.

Weinstein, W. M., Piercy, J. R. A., and Dossetor, J. B. (1974). Dermatitis herpetiformis and celiac sprue. In Coeliac Disease, pp. 361-369. Edited by W. T. J. M. Hekkens and A. S. Peña. Stenfert Kroese: Leiden.

Young, W. F., and Pringle, E. M. (1971). 110 children with coeliac disease, 1950-1969. Archives of Disease in Childhood. 46, 421-436. 